\title{
The surface quality of materials after cutting by abrasive water jet evaluated by selected methods
}

\section{Miroslava Ťavodová}

Department of Manufacturing Technology and Materials, Faculty of Environmental and Manufacturing Technology, Technical University in Zvolen, Študentská 26, 96053 Zvolen, Slovakia. tavodova@tuzvo.sk

Surface roughness is assessed on the basis of various criteria either qualitative or quantitative. The principle of qualitative methods is a subjective comparison of machined surface with the model (the standards) of the surface. The standard board is used, which corresponds to the type of surface technology, the type of an instrument, i.e. the way in which the surface was created. Its accuracy is not sufficient. Methods for expressing roughness numerically based on the defined parameters of roughness are classified as qualitative. Contact or non-contact measurement equipment is used here. Cutting material by abrasive water jet (AWJM) is one of the non-convention production technologies. The AWJ as "tool" leaves visible waviness on the machined surface. It is largely determined by the choice of the abrasive water jet feeding speed. Most of the research work qualifies the state of surface after AWJM according to roughness parameters depending on the cutting parameters. According to this knowledge the surface roughness varies linearly with increasing the cut depth. If we take feed speed as one of the quality assessment of the cutting AWJ parameters, we can watch its influence on changes the relief, (topography) of the cutting area.

Key words: qualitative and quantitative methods, hydro abrasive machining, roughness, surface waviness, profilomether

\section{References}

[1] MAŇKOVÁ, I.: 2000. Progresívne technológie. Košice: Vienala, 2000, 257 strán. ISBN 80-7099-43-4.

[2] HLOCH, S.; VALÍČEK, J.: Drsnost’ povrchu $a$ hydroabrazívne delenie, Strojárstvo : mesačník o strojárstve. Roč. 13 , č. 11 (2009), s. 86-87. - Žilina : MEDIA/ST, 2009.

[3] KALINCOVÁ, D.: Technické materiály, TU vo Zvolene, 2010, str. 95.

[4] WANG, J. Abrasive Waterjet Machining of Engineering Materials, Monograph Series, Materials Science Foundations, Volume 19, 2003, ISBN 978-0-87849-918-2. p. 27.

[5] ŠUSTEK, J. Laserový profilometer LPM s horizontálnym posunom pri sledovaní nerovnosti povrchu. In Trieskové a beztrieskové obrábanie dreva VII. medzinárodná vedecká konferencia, Technická univerzita vo Zvolene, 2010. - ISBN 978-80-2282143-8. - S. 187-192.

[6] STN EN ISO 4287:1999 Geometrické špecifikácie výrobkov (GPS). Charakter povrchu: Profilová metóda - Termíny, definície a parametre charakteru povrchu.

[7] KRAJNÝ, Z.: 1998. Vodný lúč v praxi. Bratislava, EPOS, 1998, 384 strán. ISBN 80-8057-091-4.

[8] FABIANOVÁ, J.: Význam skúmania vplyvu rezných parametrov pri rezaní vodným lúčom, Výrobné inžinierstvo, Číslo 2 , ročník VI, 2007 ss. 53-55.

[9] VALÁŠEK, P., MÜLLER, M.: Využití abrazíva z procesu děleni metodou AWJ v oblasti materiálového výzkumu. Strojírenská technologie. XVI, 2011/5, str. 37-43, ISSN1211-4162.

[10] FABIAN, S., SALOKYOVA, Š.: Experimental verification of abrasive mass flow impact on the technological head acceleration amplitude and vibrations frequency in the production system with AWJ technology. Manufacturing Technology. Volume 12, Nr. 12, 2012, pp. 18-21, ISSN 1213-2489.

[11] FABIAN, S., SALOKYOVA, Š. JACKO, P.: Experimental verification of the frequency spectrum of unwears and wears guidance tube on thetechnological head vibrations creation in the production system withAWJ technology. Manufacturing Technology. Volume 12, Nr. 13, 2012, pp. 105-108, ISSN 1213- 2489.

[12] HLOCH, S., VALÍČEK, J., SIMKULET, V., Estimation of the smooth zone maximal depth at surfaces created by Abrasive Waterjet. Surface Science and Engineering, Vol. 3, No. 4, 2009, p. 347-359, ISSN 1749-785X.

[13] SHARMA, V., CHATTOPADHYAYA, S., HLOCH, S. Multi response optimization of process parameters based on Taguchi-Fuzzy model for coal cutting by water jet technology The International Journal of Advanced Manufacturing Technology (2011) Vol. 56, pp. 1019-1025, ISSN 0268-3768.

[14] ŤAVODOVÁ, M., NÁPRSTKOVÁ, N. Hodnocení kvality povrchu materiálu po řezání AWJ, Strojírenská technologie - Roč. 17, č. 3 (2012), s. 186-192. ISSN 1211-4162. 